\title{
Unconventional Materials from Sewage Sludge with a Potential Application in a Road Construction
}

\author{
Marta Wójcik", Łukasz Bąk' ${ }^{1}$, Feliks Stachowicz ${ }^{1}$ \\ 1 Department of Materials Forming and Processing, Rzeszow University of Technology, Al. Powstańców \\ Warszawy 8, 35-959 Rzeszów, Poland \\ * Corresponding author's e-mail: m.wojcik@prz.edu.pl
}

\begin{abstract}
Limited possibilities of agricultural utilization of sewage sludge results in the development of unconventional methods of its final management. Recently, recycling of sewage sludge in road construction is under examination. Literature review mentions that properly prepared sludge might replace other conventional materials which are commonly used in a construction sector. In this paper, the proposition of the use of sewage sludge in the production of unconventional material for a road construction is presented. In laboratory tests, dewatered sewage sludge with the moisture content at the level of $62 \%$, glass powder and quartz sand were applied. For the obtained product, physical and chemical characteristics were examined. The compressive strength and the hardness were also measured. The results were compared with other materials which are also used in construction sector. The research confirmed the possibility to produce a material from different fractions of waste, which might indicate usefulness in civil engineering.
\end{abstract}

Keywords: sewage sludge, glass waste, recycling, civil engineering, road construction

\section{INTRODUCTION}

Activated sludge is one of the most popular biological processes in treatment plants which results in the production of high amount of sewage sludge. According to Bień and Wystalska [3], sewage sludge is defined as an inorganic and organic phase derived from wastewater. Sewage sludge contains approximately $2-5 \%$ of the total volume of treated wastewater. Due to the increasing number of new residents who are connected to a sewerage system and the construction as well as modernization of treatment plants and the amount of generated wastewater are systematically growing. It results in the increasing mass of sewage sludge, which is generated during wastewater treatment. According to the Central Statistical Office Report [7], 568 thousand Mg municipal sewage sludge was produced in Poland in 2015. This corresponds to the daily production approximately $40 \mathrm{~g}$ per capita. The statistics also indicate the systematically growing production of sewage sludge. One of the forecasts shows that approximately 950 thousand $\mathrm{Mg}$ of sludge will be produced in Poland in 2050 [54].

The excessive production of sewage sludge is a significant problem in Poland but also in all over the world. According to EUROSTAT [49], the annual production of sewage sludge in Europe is approximately 11 million tons. The average daily production of sewage sludge is estimated more than $55 \mathrm{~g}$ per person [3]. As reported by EUROSTAT [48], the most of sewage sludge is produced in Germany (Fig. 1). In per capita, the most of sewage sludge is generated in Austria ( $97 \mathrm{~g} / \mathrm{per}$ capita per day). On the other hand, Cyprus, Malta and Serbia are characterized by the lowest production of wastewater sludge (below $1 \mathrm{~g} /$ per capita per day).

One of the possible applications of sewage sludge is its usage in the production of different materials. Economic, social as well as environmental aspects of sustainable development caused increased interest of the application of sewage sludge in a construction industry. According to Gencel et al. [16], the construction activities have 
a)

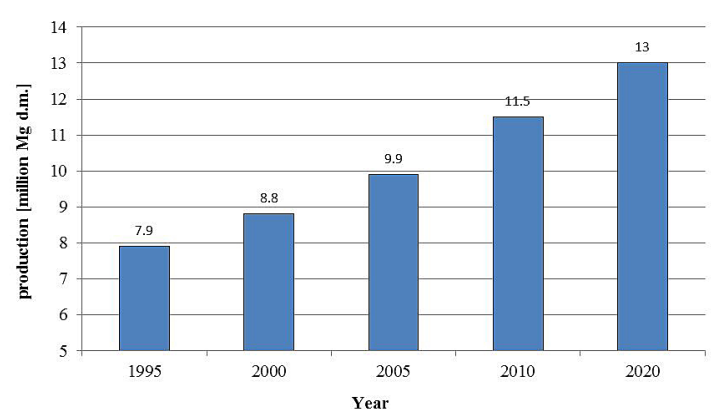

b)

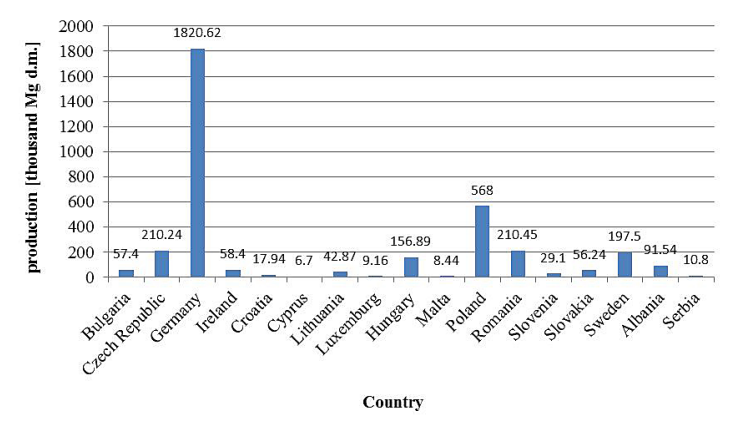

Figure 1. Production of sewage sludge in Europe (a) and in selected European countries in 2015 (b)

major influence on the sustainable development. The aforementioned method of the utilization could reduce the cost of sludge treatment and eliminate the sewage sludge storage. Additionally, the use of sewage sludge in the production of unconventional materials in a construction sector fits in the idea of the circular economy [44].

This aim of the study was to produce an unconventional material from sewage sludge and other fractions of waste. The structure and selected physical and mechanical properties of the obtained product were determined. This proposition could be a new technique in waste management which enables the utilization of different fractions of waste.

\section{APPLICATION OF SEWAGE SLUDGE AND OTHER WASTE IN A CONSTRUCTION SECTOR}

The utilization of sewage sludge and other waste in the production of different materials might be an alternative solution in the development of sustainable construction and waste management. Pavšič et al. [36] reported that the use of sewage sludge in construction is a promising approach to protect natural resources. Another advantage is the reduction of carbon dioxide emission. By means of that, the application of sewage sludge in the production of unconventional materials is desirable and an environmentally-friendly solution.

In foreign literature, there are a lot of papers concerning the application of sewage sludge in the production of building materials (Table 1). Sewage sludge alone or in conjunction with different fractions of waste might be used as:

- a component for cement production,

- a component for bricks production,

- an active additive for cementinious inorganic binders.
The usefulness of sewage sludge in a construction sector is the aim of study of many researchers. In laboratory tests, unconventional building materials derived from sewage sludge, ashes, steel dust, straw, cotton waste, rubber, rice husk ash or even cigarette butts are examined [4]. The aforementioned materials are often less expensive than traditional materials with comparable physical and chemical characteristics. Alleman and Berman [1] carried out research concerning the production of bricks from sewage sludge, clay and shale. Joan and Lázaro [28] also tested the possibility of the application of sewage sludge and clay in the production of bricks. In other studies, Chiang et al. [8] examined the properties of lightweight bricks obtained from sewage sludge, agricultural waste and rice husk ash. Badr et al. [2] also tested the possibility of replacement of clay with sewage sludge and agricultural as well as industrial waste. The obtained results showed that the product containing sludge and silica ash indicated better properties than traditional bricks.

Apart from bricks, sewage sludge might be used in the production of other building materials. Tay et al. [47] carried out research concerning the utilization of dried sewage sludge and lime dust in the production of a material similar to cement. The results proved that the obtained product has an acceptable strength characteristics in comparison to other building materials. Monzo et al. [33] also reported that it could be possible to replace cement with sewage sludge pellets in the production of Portland cement. Laboratory findings showed that cement containing sewage sludge in the amount of $15-30 \%$ has similar strength properties in comparison to traditional mortar.

One of sewage sludge utilization methods is its application in the production of unconventional lightweight aggregates. Aggregates derived from waste are a porous material which might 
Table 1. Examples of the application of sewage sludge and other waste in a construction industry

\begin{tabular}{|c|c|c|c|}
\hline No. & Type of waste & Application & Source \\
\hline 1. & sewage sludge, clay, shale & bricks production & Alleman and Berman [1] \\
\hline 2. & sewage sludge ash & bricks production & Yague et al. [56] \\
\hline 3. & sewage sludge & bricks production & Joan and Lázaro [28] \\
\hline 4. & $\begin{array}{l}\text { sewage sludge, cement, lime, } \\
\text { emulsion }\end{array}$ & pavement base layers & de Figueirédo Lopes Lucena et al. [12] \\
\hline 5. & sewage sludge & as a mineral filter in asphaltic paving mixtures & Sayed et al. [43] \\
\hline 6. & dried sewage sludge & additive in the production of cement & Lin et al. [32] \\
\hline 7. & sewage sludge & road's embankments & Oña and Osorio [35] \\
\hline 8. & $\begin{array}{l}\text { sintered sewage sludge, } \\
\text { sewage sludge ash }\end{array}$ & synthetic aggregates & Chou et al. [9] \\
\hline 9. & sewage sludge & as a component of road base layers & Leda et al. [31] \\
\hline 10. & $\begin{array}{l}\text { dewatered sewage sludge, } \\
\text { limestone powder }\end{array}$ & production of cement like material & Tay et al. [48] \\
\hline 11. & sewage sludge ash & production of ceramics materials & Suzuki et al. [46] \\
\hline 12. & sewage sludge & production of lightweight clay ceramic & Joan and Cecilia [27] \\
\hline 13. & sewage sludge ash & production of glass-ceramic material & Zhikun et al. [57] \\
\hline 14. & waste paper sludge & as an additive in the production of cement & Karada and Awchar [29] \\
\hline 15. & sewage sludge ash & $\begin{array}{l}\text { as an additive in the production of cement } \\
\text { material }\end{array}$ & Vouk et al. [52] \\
\hline
\end{tabular}

be applied in construction, architecture, gardening and geotechnical engineering [14]. In the production of unconventional aggregates, different fractions of waste might be used and of course, the most popular are materials obtained from demolition works (Fig. 2). The application of recycled aggregates can also prevent natural resources from exhaustion. According to Kozioł and Kawalec [30], production and consumption of natural aggregates in Europe is approximately 6 tons per capita. It corresponds to the annual production at the level of 3 billion tons. In Island, this consumption is above 30 tons per capita. In Poland, the production of aggregates is from 4 to 4.5 tons per capita every year among which natural aggregates are dominant. The use of recycling aggregates is relatively small and does not exceed $2.5 \%$ of all aggregates used in Poland. Nevertheless, the forecasts predict that the consumption of recycled aggregates is gradually growing, which is associated with the limited resources of raw materials [30].

The research concerning the production of aggregates from different fractions of waste, including sewage sludge was tested. This solution could transform sewage sludge into a product with a value of use [5]. Uzunow and Mazela examined the possibility of production of an artificial aggregate from sewage sludge, cullet and chalcedonite dust [50]. The obtained product had similar characteristic to other aggregates. Additionally, the aforementioned material was characterized by stable and insoluble structure. In other studied, Uzunow and Mazela [51] reported that during synthesis reaction in the temperature $1000^{\circ} \mathrm{C}$, the amorphous substance with a value of use is formed. However, during the vitrification of sewage sludge and other waste, a lot of energy in the initial stage is required. In the wake of sewage sludge sintering, the autoignition is observed. Organic compounds contained in sewage sludge are the energy career and keep the high temperature. By means of that, the energy consumption is reduced at further stages of process. It results in the decrease of costs of sewage sludge thermal utilization. Economic and environmental aspects confirm the advisability of research concerning the production of alternative materials with the use of sewage sludge [51].

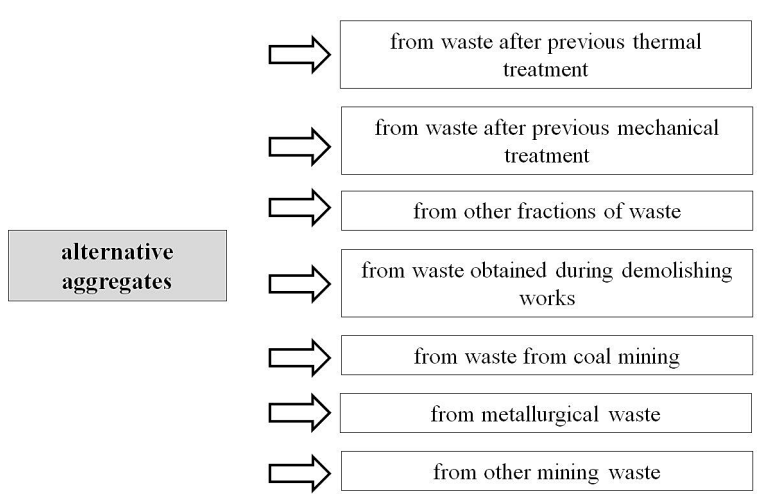

Figure 2. Examples of recycled aggregates used in engineering 


\section{Characteristics of materials}

As a main component of new material, wastewater sludge was used. In laboratory tests, sewage sludge derived from the press-filtration belt from Sędziszów Małopolski Wastewater Treatment Plant (WTTP) was used. Detailed physical and chemical characteristics of the sludge are presented in Table 2. Sewage sludge was characterized by grey and brown colour and earthy smell. It means that sludge has undergone the aerobic sludge digestion.

As other components of unconventional material, glass powder and quartz sand were applied. Glass powder is an abrasive which is obtained from milling of cullet in a milling machine (Fig. 3a). The density of glass powder is $2.5 \mathrm{~g} / \mathrm{cm}^{3}$. The aforementioned waste is an environmentallyfriendly material applicable as a flux, excipient and raising agent [22]. Additionally, the glass powder accelerates the melting process.

Quartz sand is a product of the decomposition of granite, which is characterized by the density at the level of $2.65 \mathrm{~g} / \mathrm{cm}^{3}$ (Fig. 3b). The aforementioned reagent is separated from kaolin by means of the kaolin dissolution and the dehydration of quartz. After that, quartz is washed, calcined and sieved [19]. The advantage of quartz sand is the ability to melt after heating. The fine particles transform into liquid phase which could be easily

Table 2. Characteristics of sewage sludge used in laboratory research

\begin{tabular}{|c|c|c|c|}
\hline No. & Parameter & Unit & Value \\
\hline \multicolumn{4}{|c|}{ Physical characteristics } \\
\hline 1. & $\mathrm{pH}$ & - & 6.24 \\
\hline 2. & colour & - & grey-brown \\
\hline 3. & smell & - & earthy \\
\hline 4. & dry mass & $\mathrm{g} / \mathrm{dm}^{3}$ & 380.00 \\
\hline 5. & hydration & $\%$ & 62.00 \\
\hline \multicolumn{4}{|c|}{ Chemical composition } \\
\hline 6. & nitrogen & \multirow{4}{*}{$\%$ d.m. } & 4.92 \\
\hline 7. & calcium & & 5.78 \\
\hline 8. & magnesium & & 1.05 \\
\hline 9. & phosphorus & & 1.87 \\
\hline 10. & lead & \multirow{7}{*}{ mg/kg s.m. } & 12.73 \\
\hline 11. & chromium & & 22.57 \\
\hline 12. & copper & & 98.00 \\
\hline 13. & nickel & & 17.45 \\
\hline 14. & cadmium & & $<1.00$ \\
\hline 15. & zinc & & 314.00 \\
\hline 16. & mercury & & 0.19 \\
\hline 17. & salmonella spp. & $\mathrm{cfu} / 100 \mathrm{~g}$ & not found \\
\hline 18. & $\begin{array}{l}\text { live eggs of } \\
\text { intestinal parasites }\end{array}$ & $\begin{array}{l}\text { amount/1 kg } \\
\text { d.m. }\end{array}$ & not found \\
\hline
\end{tabular}

formed. Due to the specific properties, quartz sand is commonly applied in a construction sector.

Chemical composition and the particle size distribution of quartz sand and glass powder are presented in Table 3, Table 4 and in Figure 4. There were some coarse particles in both reagents due to materials being not sieved before. It was an intentional action. By means of that, the usage of unprocessed reagents in the production of new material was tested. In terms of the chemical composition, the main component of quartz sand and glass powder was silicon oxide.

\section{METHODOLOGY}

The laboratory research included of the formation of an unconventional material with the use of dewatered sewage sludge, quartz sand and glass powder. The weight ratio of sewage sludge, glass powder and quartz sand was 1:0.5:0.5. The dosages were established on the basis of an initial research and literature review. After previous mixing, powder materials (glass powder, quartz sand) were added into sewage sludge. All components were stirred by means of the laboratory mixer for approximately 3 minutes. The obtained mixture was placed into cylindrical forms with a diameter of approximately $25 \mathrm{~mm}$ and sintered for 1 hour at

a)



b)



Fig. 3. Images of glass powder (a) and quartz sand (b) used in laboratory research 
Table 3. Chemical composition of glass powder [20]

\begin{tabular}{|c|c|c|c|}
\hline No. & Component & Unit & Value \\
\hline 1. & $\mathrm{SiO}_{2}$ & \multirow{7}{*}{$\%$} & $70.0-73.0$ \\
\hline 2. & $\mathrm{Al}_{2} \mathrm{O}_{3}$ & & $0.5-2.0$ \\
\hline 3. & $\mathrm{CaO}$ & & $7.0-11.0$ \\
\hline 4. & $\mathrm{MgO}$ & & $3.0-5.0$ \\
\hline 5. & $\mathrm{Na}_{2} \mathrm{O}+\mathrm{K}_{2} \mathrm{O}$ & & $13.0-15.0$ \\
\hline 6. & $\mathrm{Fe}_{2} \mathrm{O}_{3}$ & & $<0.1$ \\
\hline 7. & $\mathrm{TiO}_{2}$ & & $<0.1$ \\
\hline
\end{tabular}

the temperature $1100^{\circ} \mathrm{C}$. The time and the temperature were determined on the basis of initial tests.

After cooling at the room temperature, the structure, physical as well as mechanical properties of samples were examined (Table 5). SEM and SEM/EDS studies were done with the use of TESCAN VEGA 3 scanning electron microscope with detection system. The approximate hardness of the obtained material was examined by means of 10 point Mohs scale in steps of $0.5 \mathrm{HM}$. The compressive strength was measured by means of ZWICK Z100 strength testing machine. Before the compressive strength test, the samples were cut and polished. In this research, cylindrical samples with a diameter approximately $25 \mathrm{~mm}$ and a height about $50 \mathrm{~mm}$ were applied.

The compressive strength $\left(\mathrm{R}_{\mathrm{c}}\right)$ was evaluated by means of the formula (1).

$$
R_{c}=\frac{F_{c}}{S}
$$

where: $F_{c}$ - maximum load which results in the crumbling of specimen, $\mathrm{N}$;

$S$ - cross section area, $\mathrm{m}^{2}$.

The moisture absorption (n) was calculated as shown by the following equation (2).

$$
n=\frac{m_{s}-m_{d}}{m_{d}} \cdot 100 \%
$$

where: $m_{s}-$ initial mass of specimen, $g$;

$m_{d}-$ mass of specimen after drying, $\mathrm{g}$.

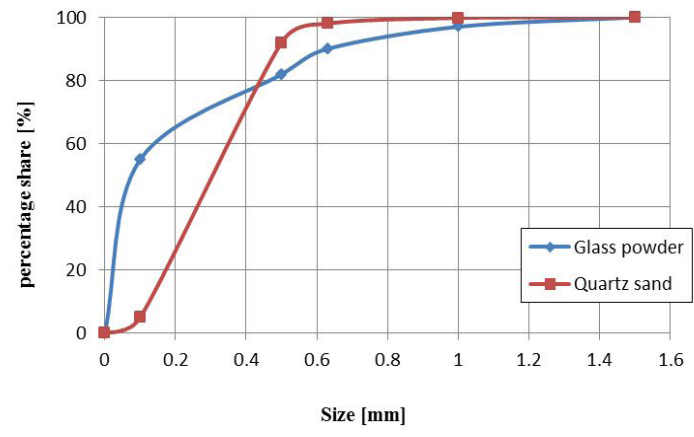

Fig. 4. Granulometric analysis of glass powder and quartz sand
Table 4. Chemical composition of quartz sand [26]

\begin{tabular}{|c|c|c|c|}
\hline No. & Component & Unit & Value \\
\hline 1. & $\mathrm{SiO}_{2}$ & & 99.3 \\
\hline 2. & $\mathrm{Fe}_{2} \mathrm{O}_{3}$ & \multirow{3}{*}{$\%$} & 0.2 \\
\hline 3. & $\mathrm{TiO}_{2}$ & & 0.1 \\
\hline 4. & $\mathrm{Al}_{2} \mathrm{O}_{3}$ & & 0.4 \\
\hline
\end{tabular}

The tightness of material (S) was calculated according to the formula (3).

$$
S=\frac{\rho_{b}}{\rho_{r}} \cdot 100 \%
$$

where: $\rho_{b}$ - bulk density, $\mathrm{g} / \mathrm{cm}^{3}$;

$\rho_{\mathrm{r}}-$ specific density, $\mathrm{g} / \mathrm{cm}^{3}$.

The porosity $(\mathrm{P})$ was calculated in the following way (4).

$$
P=[1-S] \cdot 100 \%
$$

where: $S$-tightness of material, [\%].

\section{RESULTS AND DISCUSSION}

\section{The structure and chemical characteristics of the obtained material}

After sintering, hard and porous sinter was obtained. The significant weight loss and deformation of specimens were observed. They were associated with the evaporation of water contained in sewage sludge. Under the high temperature, samples also changed the colour from brown to grey and yellow (Fig. 6). This phenomena might be caused by the addition of glass powder and quartz sans which are natural pigments.

Unconventional material produced from sewage sludge, glass powder and quartz sand has a porous structure, which was shown on SEM images (Fig. 7). In tested samples, the circular or irregular pores with a diameter up to several millimetres were dominant. It was observed that the

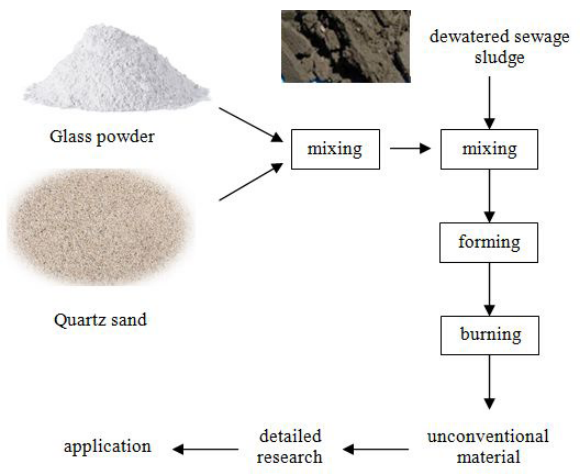

Fig. 5. Methodology of laboratory research 
Table 5. Methodology of research concerning the physical and mechanical characteristics

\begin{tabular}{|c|l|l|c|}
\hline No. & Parameter & \multicolumn{1}{c|}{ Method } & Standard \\
\hline 1. & bulk density & $\begin{array}{l}\text { hydrostatic } \\
\text { weighting }\end{array}$ & $\begin{array}{c}\text { PN-B- } \\
\text { 06714-05:1976 } \\
{[37]}\end{array}$ \\
\hline 2. & $\begin{array}{l}\text { specific } \\
\text { density }\end{array}$ & $\begin{array}{l}\text { pycnometry } \\
\text { method }\end{array}$ & $\begin{array}{c}\text { PN-EN } \\
\text { 1097-7:2008 } \\
{[39]}\end{array}$ \\
\hline 3. & $\begin{array}{l}\text { compressive } \\
\text { strength }\end{array}$ & destructive method & $\begin{array}{c}\text { PN-EN } \\
\text { 12390-3:2011 } \\
{[40]}\end{array}$ \\
\hline 4. & hardness & $\begin{array}{l}\text { Mohs hardness } \\
\text { test }\end{array}$ & - \\
\hline 5. & water & $\begin{array}{l}\text { water adsorption } \\
\text { method }\end{array}$ & $\begin{array}{c}\text { PN-EN } \\
1097-6: 2013-11 \\
{[38]}\end{array}$ \\
\hline 6. & morphology & $\begin{array}{l}\text { scanning electron } \\
\text { microscope (SEM) }\end{array}$ & - \\
\hline 7. & $\begin{array}{l}\text { chemical } \\
\text { composition }\end{array}$ & $\begin{array}{l}\text { energy- } \\
\text { dispersive X-ray } \\
\text { spectroscopy } \\
\text { (SEM/EDS) }\end{array}$ & - \\
\hline
\end{tabular}

pores have different structure. Moreover, they present a varying intensity in tested material.

The high porosity of the material is closely related to burning of organic compounds which were in sewage sludge. According to Cusidó and Cremades [11], organic compounds are totally destroyed at the temperature above $1000^{\circ} \mathrm{C}$ and the high porosity is observed. A lot interior spaces, which contain silica and oxygen, were also detected in obtained material. The voids are generated in the wake of gas-forming decomposition reactions [6]. It affects mechanical resistance, low weight and thermal and acoustic properties. The microstructure of material which contains sewage sludge is presented in Figure 8.

The analysis of the chemical composition showed that the material derived from sewage a)

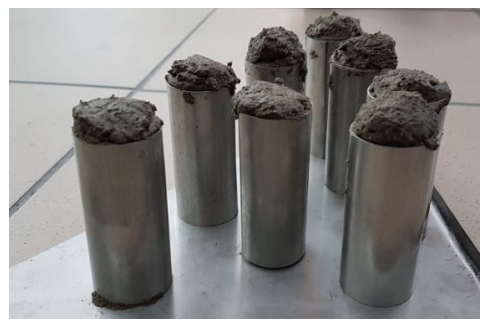

b)

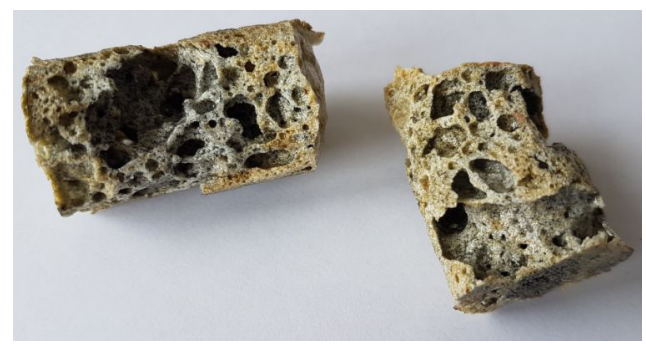

Fig. 6. Samples of material before (a) and after sintering (b)

sludge, glass powder and quartz sand comprises oxygen, calcium, sodium and silica among which oxygen and silica were dominant (Fig. 9, Table 6). For expanded clay aggregate modified with the use of glauconite, silica is also a dominant compound [14]. The high content of silica is related to its presence in powder materials, which are applied to sewage sludge. The presence of sodium and calcium in obtained material is associated with their content in sewage sludge.

\section{The physical characteristics of obtained material}

The specific density of the obtained materials was determined by means of pycnometry method in accordance with PN-EN 1097-7:2008 [37]. The specific density of material containing a)

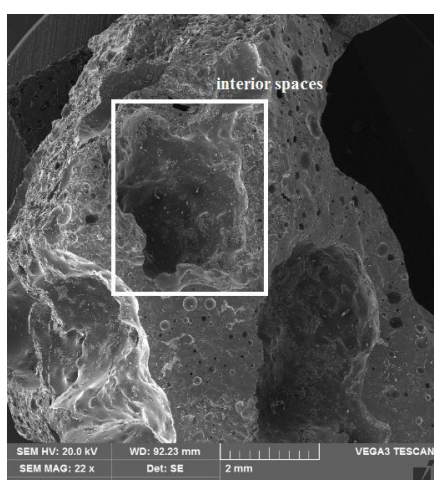

b)

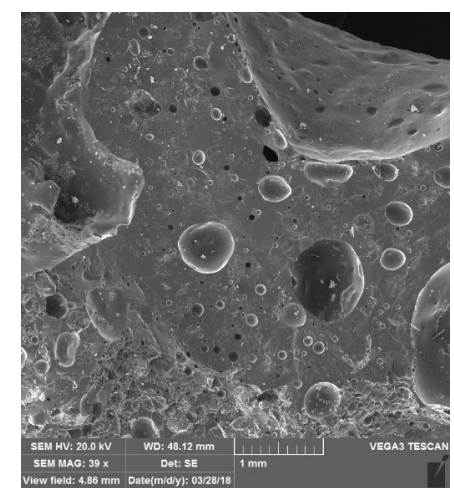

c)

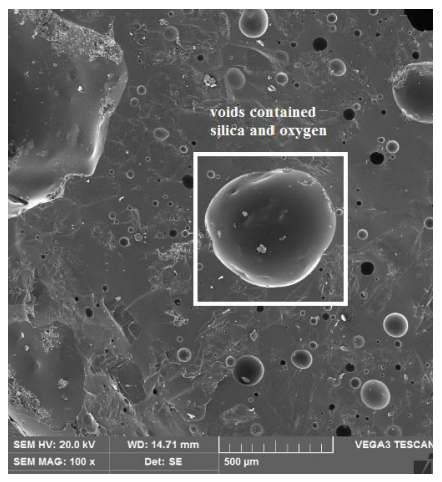

Fig. 7. SEM images of material from sewage sludge, glass powder and quartz sand at different magnifications: $22 x(a), 39 x(b)$ and 100x (c) 




Figure 8. The microstructure of the material from sewage sludge, glass powder and quartz sand (based on [11])

sewage sludge and other waste was $2.84 \mathrm{~g} / \mathrm{cm}^{3}$ (Table 7). In comparison to other materials which are commonly applied in a construction sector, the specific density of samples is similar to concrete (approximately $2.80 \mathrm{~g} / \mathrm{cm}^{3}$ ) [45]. The porous materials, for example expanded clay aggregate, are characterized by lower specific density (approximately $\left.2.5-2.6 \mathrm{~g} / \mathrm{cm}^{3}\right)[13,14]$.

The bulk density of materials is closely related with its structure and porosity. The higher value of bulk density might suggest that the material is more compact. Additionally, the higher value of the aforementioned parameter can also denote the higher compressive strength [10]. The bulk density of samples was examined by the use of hydrostatic weighting in line with PN-B06714-05:1976 [37]. The aforementioned parameter of the obtained material was $1.30 \mathrm{~g} / \mathrm{cm}^{3}$ (see Table 7) and was similar to the expanded clay aggregate $\left(0.9-1.5 \mathrm{~g} / \mathrm{cm}^{3}\right)$ [14]. The artificial aggregates, for example ceramic aggregates, are characterized by the higher value of bulk density $\left(2.43 \mathrm{~g} / \mathrm{cm}^{3}\right)$ [17]. In terms of the bulk density, the material produced from sewage sludge, glass powder and quartz sand might be classified as a lightweight aggregate with a bulk density below $2.0 \mathrm{~g} / \mathrm{cm}^{3}[55]$.

The tightness of material is defined as a volume fraction of a solid material per unit volume. The higher value of the aforementioned parameter suggests that the material is less porous. The obtained material was characterized by the tightness at the level of $45.78 \%$ (see Table 7). It indicates that approximately $46 \%$ of material is without pores. The analysis of the result showed that the tightness of material was relatively low and samples were very porous. In comparison to other materials which are commonly applied in
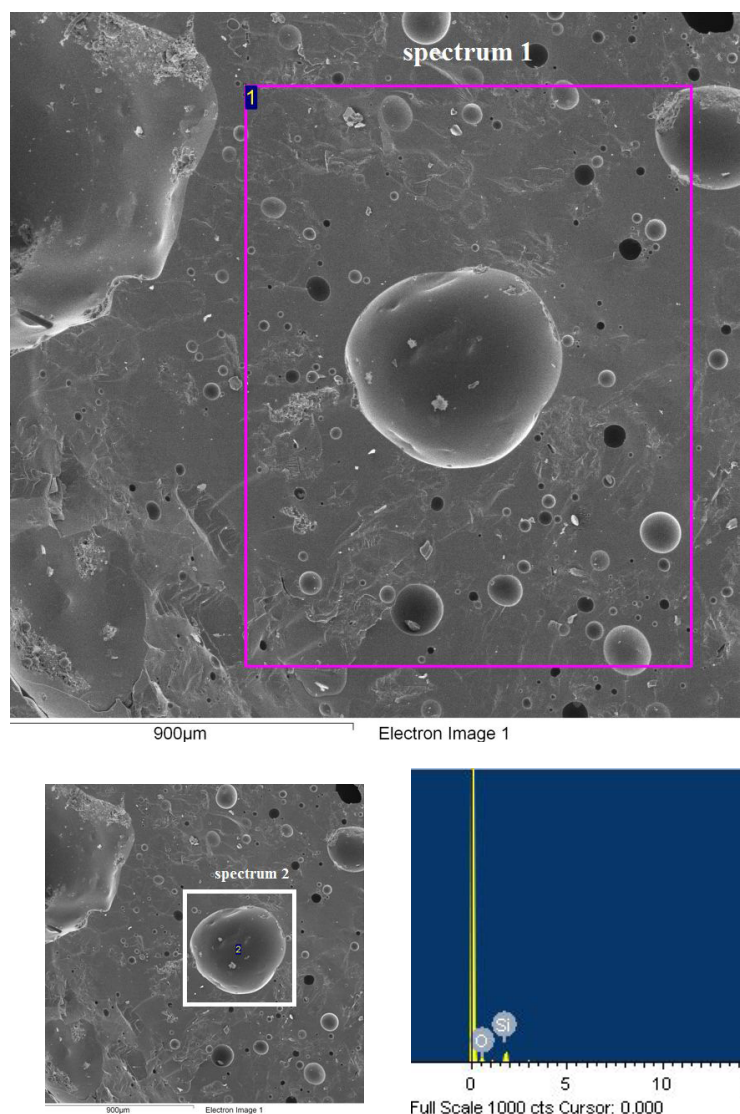
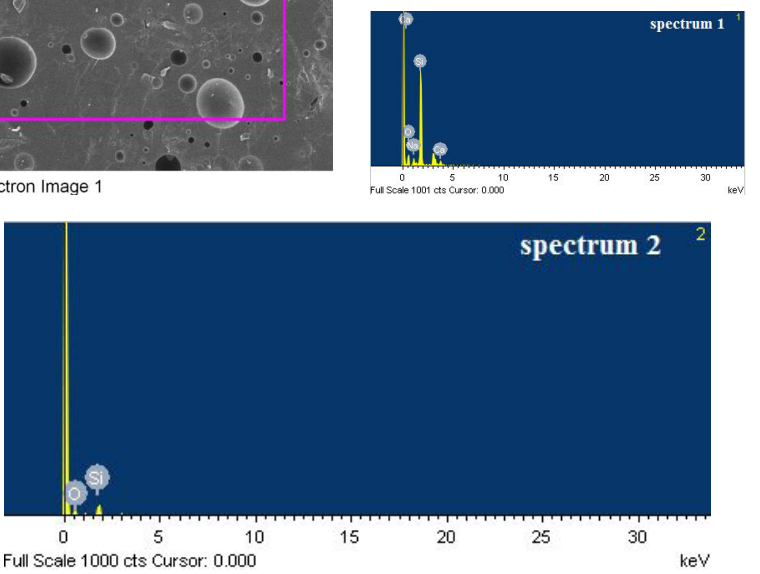

Fig. 9. Results of SEM/EDS research 
Table 6. Chemical composition of material by means of SEM/EDS research

\begin{tabular}{|c|c|c|}
\hline \multirow{2}{*}{ Compound } & \multicolumn{2}{|c|}{ Content [\%] } \\
\cline { 2 - 3 } & minimum & maximum \\
\hline $\mathrm{O}$ & 36.23 & 61.14 \\
\hline $\mathrm{Na}$ & 5.33 & 5.33 \\
\hline $\mathrm{Si}$ & 38.86 & 52.83 \\
\hline $\mathrm{Ca}$ & 5.61 & 5.61 \\
\hline
\end{tabular}

a construction building, the tightness of the obtained material is similar to the expanded clay aggregate. According to Franus et al. [14], the tightness of expanded clay aggregate is approximately $48 \%$. In comparison to concrete, the material produced from sewage sludge and other waste is characterized by the much lower tightness [50].

The porosity of the obtained material was $54.22 \%$ and confirmed that samples were very porous (see Table 6). In comparison to other materials, the aforementioned parameter is similar to expanded clay aggregate, whose porosity is at the level of $20-50 \%$. Concrete is characterized by the significantly lower porosity (8-12\%) [45]. According to Franus et al. [14], the high porosity influences on the infiltration properties of a material. Due to the specific structure and characteristics, the aforementioned material might be also used as an acoustic insulation.

The water adsorption is defined as the ability of material to adsorb water under certain conditions. The aforementioned parameter might be also used for the evaluation of the stability of a construction. The water adsorption of obtained material is in the range of 5.56-16.70\%, depending on time of the action of water (Fig. 10). It has been demonstrated that the material changed the value of the water adsorption within $15-20 \mathrm{~min}$ utes. After this time, the aforementioned parameter did not change. The water adsorption of obtained material is closely related with the amount and the size of pores [10].

In comparison to other materials, water adsorption of the tested material is lower than for expanded clay aggregate, which is approximately $18-30 \%$. According to Uzunow and Mazela [50], the water adsorption of aggregate obtained from sewage sludge and other waste was higher and was approximately $13 \%$ after 1 minute of the action of water. Other aggregates commonly used in a construction sector are characterized by the lower value of the aforementioned parameter (below 8\%) [21, 53]. However, Ogrodnik et al. [34] indicated that the recycled aggregates derived
Table 7. Selected parameters of material produced from sewage sludge, glass powder and quartz sand

\begin{tabular}{|c|l|c|c|}
\hline No. & \multicolumn{1}{|c|}{ Parameter } & Unit & Value \\
\hline 1. & specific density & $\mathrm{g} / \mathrm{cm}^{3}$ & 2.84 \\
\hline 2. & bulk density & $\mathrm{g} / \mathrm{cm}^{3}$ & 1.30 \\
\hline 3. & tightness & $\%$ & 45.78 \\
\hline 4. & porosity & $\%$ & 54.22 \\
\hline
\end{tabular}

from ceramics are characterized by the water adsorption at the level of $22 \%$. It means that the material obtained from sewage sludge, glass powder and quartz sand might be considered as an unconventional aggregate with a potential value in a road construction.

\section{The mechanical characteristics of the obtained material}

Due to the high porosity of the material, the hardness was assessed with the use of Mohs hardness test. On the basis of Mohs scale, the hardness of samples was at the level of 3.5 HM (Hardness of Mohs). It means that the unconventional material produced from sewage sludge and other waste is a medium hard and might be cracked by means of a copper wire. Similar hardness has dolomite gravel which is used as a natural aggregate [25]. In contrast, granite and basalt aggregates are characterized by the hardness of approximately 6-8 HM [23].

One of the main parameters which determines the suitability of material in a road construction is the compressive strength. The aforementioned parameter was determined by means of the strength testing machine in accordance with PN-EN 12390-3:2011 [40] (Fig. 11a). Before the compressive strength test, the samples were properly prepared (Fig. 11b). The analysis of the results showed that the mean compressive strength for tested material was $2.93 \mathrm{MPa}$ (Table 8). The value of destructive force for three representative

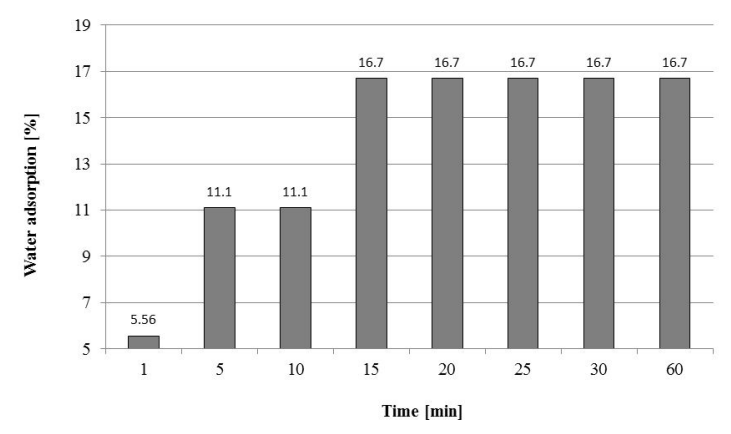

Fig. 10. The water adsorption of material used in a laboratory research 
samples was at the level of 1251-1650 N (Fig. 12). The differences between samples were caused by the inhomogeneity of the material and the various distribution of pores within specimens. However, differences between compressive strength of specimens do not exceed $15 \%$. In comparison to other materials, the aforementioned parameter is similar to expanded clay aggregate, for which compressive strength is approximately $0.75-5.00$ $\mathrm{MPa}[15,24]$. Nevertheless other aggregates which are used, for example in a production of cement, are characterized by the compressive strength at the level of 5-7 MPa [18]. The lower value of the aforementioned parameter in comparison to other aggregates is closely related with the high porosity of material.

The application of aggregates in a road construction is limited by Polish law and construction standards. WT-42010 standard determines the physical, chemical and mechanical parameters of materials which can be used in the construction of road [18]. In line with WT-42010, PN-EN 13242+A1:2010 [41] and PN-S-96012:1997 [42], the hydraulic bounded aggregate obtained from sewage sludge, glass powder and quartz glass meets the requirements and might be used as a layer in a road construction.

\section{CONCLUSIONS}

In laboratory tests, unconventional material derived from sewage sludge, glass powder and quartz sand was achieved. The obtained results proved that under $1500^{\circ} \mathrm{C}$ it is possible to achieve an amorphous substance with aggregate properties. The material produced from sewage sludge and other waste is characterized by the specific and bulk density approximately 2.8 and $1.3 \mathrm{~g} / \mathrm{cm}^{3}$, respectively. Due to the presence of organic compounds in sewage sludge and their destruction in a temperature above $1000^{\circ} \mathrm{C}$, the obtained material was also characterized by the high porosity. The size and distribution of pores within material affect water adsorption and mechanical properties. In terms of the structure and physical properties, material derived from sewage sludge, glass powder and quartz sand is similar to expanded clay aggregate, which is applied in many sectors of economy, including in a construction sector.

The tested material is characterized by medium hardness at the level of $3.5 \mathrm{HM}$. The compressive strength is approximately $2.93 \mathrm{MPa}$. In a)

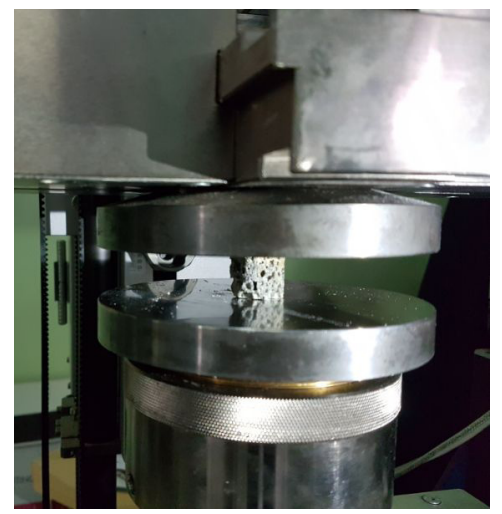

b)

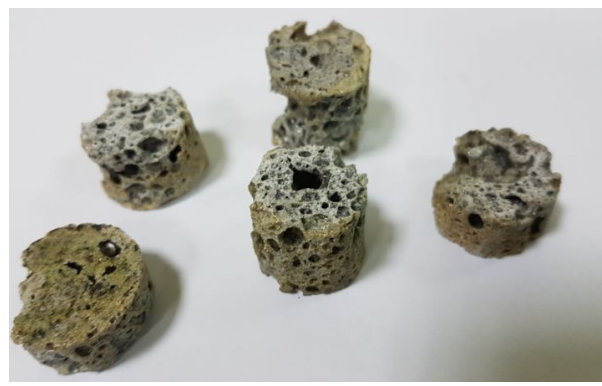

Fig. 11. The compression test for material from sewage sludge, glass powder and quartz sand (a) and samples before compressive strength test (b)

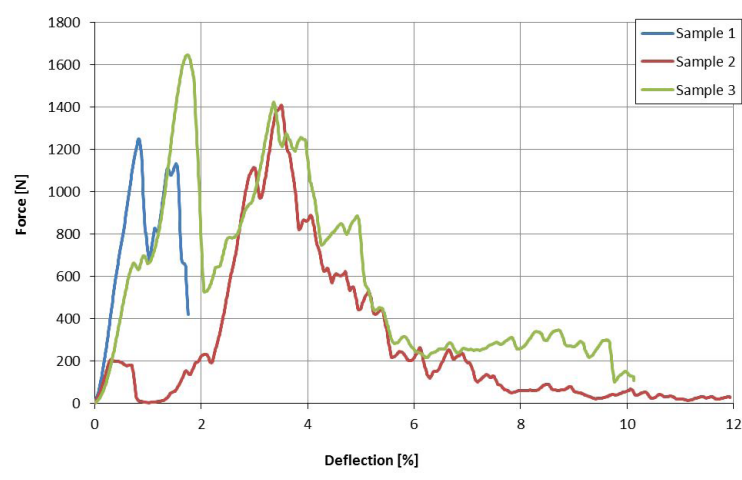

Fig. 12. The stress-strain relationship for material from sewage sludge, glass powder and quartz sand

Table 8. Compressive strength for material produced from sewage sludge, glass powder and quartz sand

\begin{tabular}{|c|c|c|}
\hline $\begin{array}{c}\text { Number of } \\
\text { sample }\end{array}$ & $\begin{array}{c}\text { The destructive } \\
\text { force }[\mathrm{N}]\end{array}$ & $\begin{array}{c}\text { Compressive } \\
\text { strength [MPa] }\end{array}$ \\
\hline 1 & 1251.67 & 2.55 \\
\hline 2 & 1410.54 & 2.87 \\
\hline 3 & 1646.75 & 3.35 \\
\hline $\mathrm{M}[\mathrm{MPa}]$ & 1436.32 & 2.93 \\
\hline SD [MPa] & 198.80 & 0.40 \\
\hline $\mathrm{CV}[-]$ & 0.1384 & 0.1384 \\
\hline CV [\%] & 13.84 & 13.84 \\
\hline
\end{tabular}


line with construction standards, the aggregate obtained from sewage sludge, glass powder and quartz glass related hydraulic binder can be used as a layer in a pavement design. By means of that, it will be possible to convert sewage sludge in a material with a high value of use. The aforementioned solution also enables the recycling of sludge in accordance with waste hierarchy.

The results of laboratory tests confirm the validity of further research concerning the application of sewage sludge in a construction sector. Further tests will focus on the decrease of porosity and the increase of hardness and compressive strength of materials.

\section{REFERENCES}

1. Alleman J.E. and Berman N.A. Constructive sludge management: Biobrick. Journal of Environmental Engineering, 110(2), 1984, 301-311.

2. Badr E.D.E.H., Hanan A.F. and Ahmed M.H. Incorporation of water sludge, silica fume and rice husk ash in brick making. Advances in Environmental Research, 1, 2012, 83-96.

3. Bień J. and Wystalska K. Osady ściekowe. Teoria i praktyka. Politechnika Częstochowska Publishing House, 2011.

4. Borowski G. Using vitrification for sewage sludge combustion ash disposal. Polish Journal of Environmental Studies, 24(5), 2015, 1889-1896.

5. Borowski G. Suitability tests of fly ashes vitrification from sewage sludge incineration. Archives of Environmental Protection, 38(2), 2012, 81-87.

6. Cheesman, C.R. and Virdi, G.S. Properties of microstructure of lightweight aggregate produced from sintered sewage sludge ash. Resources, Conservation \& Recycling, 45(1), 2005, 18-30.

7. Central Statistical Office Report. Environmental Protection, 2016.

8. Chiang K.Y., Chou P.H., Hua C.R., Chien K.L. and Cheeseman C. Lightweight bricks manufactured from water treatment sludge and rice husks. Journal of Hazardous Materials, 171, 2009, 76-82.

9. Chou I.J., Wang K.S., Chen C.H. and Lin Y.T. Lightweight aggregate made from sewage sludge and incinerated ash. Waste Management, 26, 2006, 1453-1461.

10. Ciak N., Ciak M. and Łuba-Dunajska J. Właściwości betonu lekkiego na bazie wermikulitu. Materiały Budowlane, 10, 2017, 41-43.

11. Cusidó J.A. and Cremades L.V. Environmental effects of using clay bricks produced with sewage sludge: Leachability and toxicity studies. Waste Management, 32, 2012, 1202-1208.
12. de Figueirédo Lopes Lucena L.C., Juca J.F.T., Soares J.B. and Portela M.G. Potential Uses of Sewage Sludge in Highway Construction. Journal of Materials in Civil Engineering, 26(9), 2014, 04014051.

13. Franus M. and Bandura L. Właściwości kruszyw lekkich modyfikowanych zużytymi sorbentami mineralnymi. Budownictwo i Architektura, 13(2), 2014, 73-83.

14. Franus M. Właściwości fizyczne i mechaniczne keramzytu otrzymanego z dodatkiem glaukonitu. Budownictwo i Architektura, 10, 2012, 5-14.

15. Gawenda T., Naziemiec T. and Walerak A. Badania wybranych właściwości kruszyw z odpadów ceramicznych oraz betonu wytworzonego $\mathrm{z}$ ich udziałem. Annual Set of The Environment Protection, 15, 2013, 2003-2021.

16. Gencel O., Ozel C., Koksal F., Erdogmus E., Martinez-Barrera G. and Bostow W. Properties of concrete paving blocks made with waste marble. Journal of Cleaner Production, 21, 2012, 62-70.

17. Góralczyk S. and Kukielska D. Jakość krajowych kruszyw. Górnictwo i Geoinżynieria, 34(4), 2010, 211-224.

18. WT-4 2010 Wymagania Techniczne „Mieszanki niezwiązane do dróg krajowych".

19. http://euromineral.com.ua/pl (access: 03.04.2018).

20. http://sklep.kepka.com.pl/katalog/produkt/maczkaszklana/853 (access: 03.04.2018).

21. http://topgranit.pl/kamien/bazalt/ (access:03.04. 2018).

22. http://www.artglas-recykling.pl/maczka-szklana. html (access: 03.04.2018).

23. http://www.brukstore.pl/p193/tluczen-dolomitowy315-63-mm-loco-rybnik (access: 03.04.2018).

24. https://informatorbudownictwa.pl/fundamenty-sciany-stropy/elementy-keramzytobetonowe/keramzytsystem/p/18660-bloczek-fundamentowy-keramzytowy (access: 03.04.2018).

25.https://leca.pl/sites/default/files/04-produkty/1izolacje/1-atesty/DoP-2015/DoP-LecaKeramzyt-izolacyjny-L-2015.pdf (access: 03.04. 2018).

26. https://www.gorazdze.pl/pl/piasek_suszony_kwarcowy (access: 03.04.2018).

27. Joan A.C. and Cecilia S. Valorization of pellets from municipal WWTP sludge in lightweight clay ceramics. Waste Management, 31(6), 2011, 1372-1380.

28. Joan A.C. and Lázaro V.C. Environmental effects of using clay bricks produced with sewage sludge: Leachability and toxicity studies. Waste Management, 32(6), 2012, 1202-1208.

29. KaradaA.G. andAwchat G.D.AReview on Partial Replacement of Fine Aggregate by Waste Paper Sludge in Concrete. International Journal of Computer Sci- 
ence and Mobile Computing, 6(6), 2017, 369-376.

30. Kozioł W. and Kawalec P. Kruszywa alterantywne w budownictwie, Nowoczesne Budownictwo Inżynieryjne, 4, 2008, 34-37.

31. Leda C., de Figueiredo lopes Lucena L., Thome Juca J., Soares J. and Portela M. Potential uses of sewage sludge in highway construction. Journal of Materials in Civil Engineering, 26(9), 2013, 04014051.

32. Lin Y., Zhou S., Li F. and Lin Y. Utilization of municipal sewage sludge as additives for the production of eco-cement, Journal of Hazardous Materials, 30, 2012, 213-214.

33. Monzo J., Paya J., Borrachero M.V., Morenilla J.J., Bonilla M. and Calderon P. Some strategies for reusing residues from waste water treatment plants: Preparation of building materials. Proc. of the Conference on the Use of Recycled Material in Building and Structures, Barcelona 2004, 15-18.

34. Ogrodnik P., Zegardło B. and Pieniak D. Badanie twardości jako metoda oceny jakości recyklingowych kruszyw ceramicznych do betonów. Zeszyty Naukowe SGSP, 2(62), 2017, 25-37.

35. Oña J.D. and Osorio F. Application of sludge from urban wastewater treatment plants in road's embankments. Journal of Hazardous Materials, 131, 2006, 37-45.

36. Pavšič P., Mladenovič A., Mauko A., Kramar S., Dolenec M., Vončina E., Pavšič Vrtač K. and Bukovec P. Sewage sludge/biomass ash based products for sustainable construction. Journal of Cleaner Production, 67, 2014, 117-124.

37. PN-B-06714-05:1976 Kruszywa mineralne Badania - Oznaczanie gęstości pozornej na wadze hydrostatycznej.

38. PN-EN 1097-6:2013-11 Badania mechanicznych i fizycznych właściwości kruszyw - Część 6: Oznaczanie gęstości ziaren i nasiąkliwości.

39. PN-EN 1097-7:2008 Badania mechanicznych i fizycznych właściwości kruszyw - Część 7: Oznaczanie gęstości wypełniacza - Metoda piknometryczna.

40. PN-EN 12390-3:2011 Badania betonu - Część 3: Wytrzymałość na ściskanie próbek do badań.

41. PN-EN 13242+A1:2010 Kruszywa do niezwiązanych i związanych hydraulicznie materiałów stosowanych w obiektach budowlanych i budownictwie drogowym.

42. PN-S-96012:1997 Drogi samochodowe - Podbudowa i ulepszone podłoże $\mathrm{z}$ gruntu stabilizowanego cementem.

43. Sayed M.H.A., Madany I.M. and Buali A.R.M. Use of sewage sludge ash in asphaltic paving mixes in hot regions. Construction and Building Materials, 9(1), 1995, 19-23.

44. Smol M., Kulczycka J., Henclik A., Gorazda K. and Wzorek $Z$. The possible use of sewage sludge ash (SSA) in the construction as a way towards a circular economy. Journal of Cleaner Production, 95, 2015, 45-54.

45. Stefańczyk B. Budownictwo Ogólne. Tom 1 Materiały i wyroby budowlane. Arkady, 2005.

46. Suzuki S., Tanaka M. and Kaneko T. Glassceramic from sewage sludge ash. Journal of Material Science, 32(7), 1997, 1775-1779.

47. Tay J.H., Show K.Y., Hong S.Y., Chien C.Y. and Lee D.J. Potential reuse of wastewater sludge for innovative applications in construction aggregates. Water Science and Technology, 50(9), 2002, 189-196.

48. Tay J.H. and Show K.Y. Utilization of municipal wastewater sludge as building and construction material. Resources, Conservation and Recycling, 6(3), 1992, 191-204.

49. The statistical office of the European Union. Sewage sludge production and disposal from urban wastewater 2016.

50. Uzunow E. and Mazela A. Badanie technologii produkcji kruszyw sztucznych $\mathrm{z}$ osadów ściekowych zanieczyszczonych związkami metali ciężkich. Forum Eksploatatora, 39(6), 2008, 64-68.

51. Uzunow E. and Mazela A.: Lekkie kruszywo sztuczne z osadów ściekowych. Ekopartner, 209(3), 2009, 14-15.

52. Vouk D., Nakic D., Štirmer N. and Baricevic A. Effect of lime addition during sewage sludge treatment on characteristics of resulting SSA when it is used in cementitious materials. Water Science and Technology, 75(3-4), 2017, 856-863.

53. Wawrzeńczyk J., Molendowska A. and Kłak A. Wpływ wybranych czynników na wyniki badań nasiąkliwości betonu. Budownictwo i Architektura, 12(3), 2013, 239-246.

54. Wieremiej W., Kuziemska B., Pieniak-Lendzion K., Trębicka J. and Wyrębek H. Prawne aspekty przyrodniczego wykorzystania osadów ściekowych. Zeszyty Naukowe Uniwersytetu Przyrodniczo-Humanistycznego w Siedlcach Seria: Administracja i Zarządzanie, 104, 2015, 207-218.

55. Wolska-Kotańska C. Normy PN-EN w zakresie metod badań kruszyw mineralnych ustanowione w 2003 r. Building Research Institute - Quartely, 129(1), 2004, 27-34.

56. Yague A., Valls S., Vazquez E. and Cushion V. Use of dry sludge from waste water treatment plants as an additive in prefabricated concrete bricks. Construction and Building Materials, 267, 2002, 31-41.

57. Zhikun Z., Zhang L., Yin Y. and Liang X., Li A. The recycling of incinerated sewage sludge ash as a raw material for $\mathrm{CaO}-\mathrm{Al}_{2} \mathrm{O}_{3}-\mathrm{SiO}_{2}-\mathrm{P}_{2} \mathrm{O}_{5}$ glassceramic production. Environmental Technology, 36(9), 2015, 1098-1103. 